\title{
沖縄地方の赤土流出抑制に向けた 流域経営システムの市場に関する研究
}

\author{
宮本善和 ${ }^{1} \cdot$ 成瀬研治 $^{2} \cdot$ 松下潤 $^{3}$ \\ ${ }^{1}$ 正会員 中央開発株式会社 環境防災事業部（T169-8612 東京都新宿区西早稲田 3-13-5） \\ E-mail:miyamoto@ckcnet.co.jp \\ ${ }^{2}$ 中央開発株式会社 環境防災事業部（テ169-8612 東京都新宿区西早稲田 3-13-5） \\ E-mail:naruse@ckcnet.co.jp \\ ${ }^{3}$ 正会員 芝浦工業大学教授 システム工学部 環境システム学科（テ330-0003 埼玉県大宮市深作 307） \\ E-mail: matusita@sic.shibaura-it.ac.jp

\begin{abstract}
沖縄地方のサンゴ礁の保全·再生に向け, 農地の赤土流出抑制とサンゴ増殖の対策を支援する基金の設 立可能性を探るため, 八重山諸島の観光マーケットの圈域住民を対象に行ったインターネット調查の結 果を分析・考察した. その結果, (1) 観光客にサンゴ礁に触れる機会を設けて関心を高めることが有効で ある，(2) 保全·再生への観光客の年間資金提供額は 3,000 円以下で, ターゲットを設定し適当なインセ ンティブと回収方法を工夫することが有効である，(3) サンゴ礁の保全·再生の関連企画には 10,000 円以 下の支払が望め, サンゴ礁の生態·実態観察ツアーの企画開発が有効である, (4) 5 つの観光夕イプに応 じたツアーと組合せ保全·再生に参加・協力を求めることが有効であるなどが確認された.
\end{abstract}

Key Words : watershed management, fund system, coral reef, soil erosion, marketing research

\section{1. はじめに}

沖縄地方では，近年，陸域からの赤土土壤や污水等の 流出が顕著になり，沿岸域の污染によってサンゴ礁の生 態系の劣化が重大な問題となっている. 沖縄県は1994 年 に「赤土等流出防止条例」を制定したが，現在の赤土の 主要な発生面源である農耕地での具体的な規制や対策は 不十分である. 加えて, 沖縄における農業は零細で, 経 営基盤か溺く, 対策まで考慮した営農活動を自発的に行 うことは困難である.

このような問題解決のため, 著者らは様々な関連分野 の研究者と研究コンソーシアムを構成して実効的な研究 成果を求めて研究を展開している. 既に, 大澤 ${ }^{1}$ は, 石垣 島での農地の現地観測や数値シミュレーションを行い, 農地でのサトウキビ植付け時期を工夫する, 株出しなど の栽培方法を工夫する, 緑肥作物による被覆を行うなど の農地対策が有効であることを確認している. また, 岡 本ら ${ }^{2}$ はサンコ礁再生技術を開発し; サンゴ増殖の実験的 研究を進めている. そして, 著者ら ${ }^{3449}$ は, このような ハード対策を補完・促進するためのソフト対策として,
流域経営システムの構築を検討している（図-1）. 即ち, 陸域における農地での赤土流出抑制の対策や，海域にお けるサンゴ増殖などの対策を資金面から支援するための 基金を創設し，観光客などの受益者から資金提供を求め るとともに，様々な対策プログラムの活発化に多様なス テークホルダーの参加・協力を求めていこうとするもの である. そのためには, 流域経営システムの動力源であ

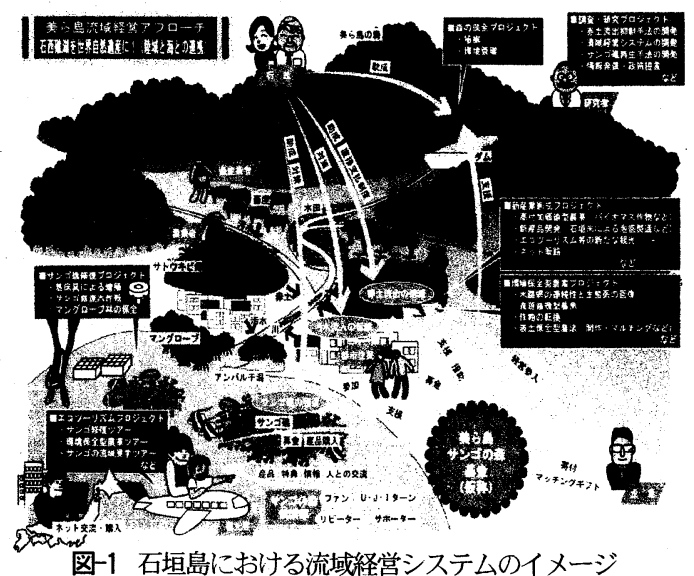


る基金の市場を明らかにするとともに，効果的に資金を 集めるためのマーケティングが必要である.

地域の環境保全における環境経済面の既往研究として は, CVM 法やコンジョイント分析などによって環境保全対 象の経済価値を評価するものが多い6788. このような研 究は, 環境保全対象の評価, 政策判断, 合意形成などに 有益であるが，環境保全のための資金回収手段やそのた めのマーケティングまでは扱っていないものが多い，一 方，税金に代替する資金を環境保全に充当する取組み上 しては，エコツアー，住民参加型ミ二市場公募債，市民 ファンド，地域通貨など，椂々な手法が各地で試行され ている. また, このような手法を援用した環境保全の経 営システムを検討した研究 9101111) は試みられ始めている が, 今後さらなる研究の蓄積が必要であり, 本研究はそ の一つとして位置づけられる.

本研究は, このような背景を受け, 沖縄地方の赤土流 出抑制とサンコ礁保全·再生の対策を補完·促進するため の流域経営システムの確立に向け，その動力源である基 金の市場について分析する. そのため，八重山諸島の観 光マーケット圈域の住民を対象にインターネット調査を 行い，(1) サンコ礁危機への関心，(2) サンコ礁の保全・ 再生に対する資金提供の意思とその傾向について統計分 析を行った上で，(3) 観光とサンゴ礁保全·再生のリンク のあり方について分析・考察を行うものである.

\section{2. 八重山諸島の観光マーケットの圏域住民に対す るインターネット調査}

八重山諸島のサンゴ礁の保全·再生に対する観光客の 意識と資金協力の可能性を明らかにするため，八重山諸 島の観光マーケットの圏域住民を対象として Keb による インターネット調査を行った.

インターネット調査は，あらかじめ登録されたモニタ 一に対して Web 画面を通して回答を得る方式の調查で, 近年のパソコンとインターネットの国民的普及を背景に マーケティング調查などで多用されている.インターネ ット調査は, 回答者の年齢に偏りがあるなどのサンプル バイアスが指摘されている反面，郵送アンケート調查な どに比べて時間や費用が少なく，広域から大量の回答を 得ることができ，回答や入力のミスが少ないなどの長所 がある. また，今後の観光客は観光情報や特産品などの 情報をインターネットで入手する機会が多くなると考え られることから，インターネットユーザーを対象とした 調査が適当と考えた。

インターネット調査のサンプルバイアスの低減を図る ため，民間調査会社（マーケティングテクノロジー株式 会社）が有する 20 歳以上の登録モニター（約 40 万人）
に対して，八重山諸島の主要航路の圈域住民（東京圏 : 東京都・神奈川県・埼玉県・千葉県, 大阪圈 : 京都府・ 大阪府・兵庫県 $\cdot$ 奈良県, 名古屋圏 : 愛知県 $\cdot$ 岐阜県 三重県, 福岡圏 : 福岡県・佐賀県, 沖縄圏 : 沖縄県本島) の人口構成比，年齢構成比，性別構成比を反映させた严 ンプリングを行った. 具体的には，八重山諸島の観光統 計など ${ }^{1213}$ 13 から主要航路の入域観光客数の圏域別比率を 求め, その圈域別比率に応じて回収目標のサンプル数 $(\mathrm{n}=1,000)$ を割り振つた上で，さらに圏域別人口の年齢 層（20 歳代，30 歳代，40 歳代，50 歳以上）之性別で割 り振ったサンプル数を算出した. そして，登録モニター に電子メールで依頼を行い，用意した Web 画面（図-2） にアクセスして回答を入力してもらい，各圏域の年跉層 別, 性別のサンプル数に達した時点で $\mathrm{Web}$ 画面を閉じた.

この際，多重回答防止，ミス・未入力回答のチェック を行っている. 回収状況は表-1，図-3 の通りで，沖縄圏 の高年齢層で月標に達しなかったが，その他は目標のサ

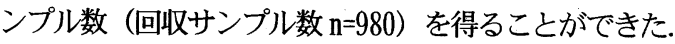

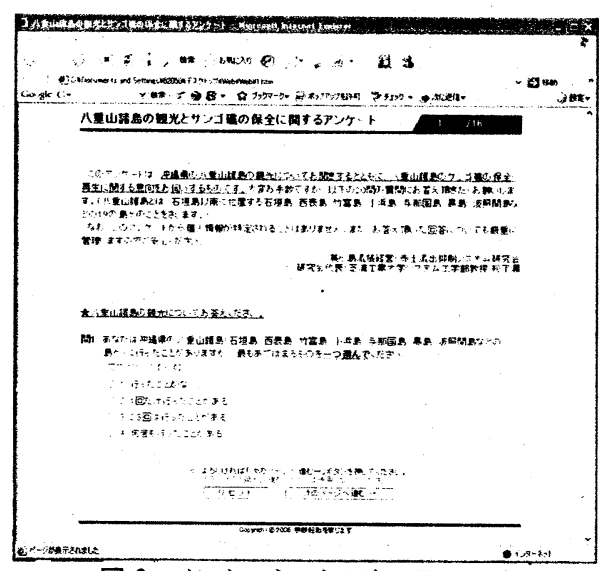

図-2 インターネット調査の Web 画面

表1 インターネット調査回収状况

\begin{tabular}{|c|c|c|c|c|}
\hline $\begin{array}{c}\text { 主要航路 } \\
\text { の圈域 }\end{array}$ & $\begin{array}{c}\text { 圈域別 } \\
\text { 比率 }\end{array}$ & $\begin{array}{l}\text { 想定 } \\
\text { 回収数 }\end{array}$ & 回収数 & 回収率 \\
\hline 東京圈 & $38.8 \%$ & 388 & 388 & $100.0 \%$ \\
\hline 大阪圈 & $24.1 \%$ & 241 & 241 & $100.0 \%$ \\
\hline 名古屋圈 & $9.5 \%$ & 95 & 95 & $100.0 \%$ \\
\hline 福岡圈 & $12.0 \%$ & 120 & 120 & $100.0 \%$ \\
\hline 沖縄圈 & $15.6 \%$ & 156 & 136 & $87.2 \%$ \\
\hline 合計 & $100.0 \%$ & 1000 & 980 & $98.0 \%$ \\
\hline
\end{tabular}

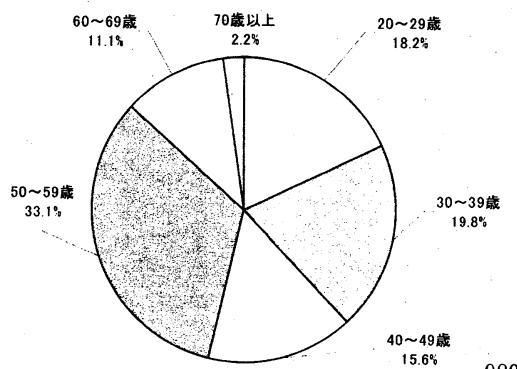

図-3 インターネット調査の年龄層 $\mathrm{n}=980$ 
設問は計 20 問で, (1) 八重山諸島の観光経験や二ーズ, (2) サンコ礁の危機に対する関心，(3) サンコ礁の保全·再 生に関する考え方，(4) 保全·再生に対する資金提供の意 思，(5) 基本属性 (年齢・性別等)などである. 設問項目を 表-2 に示す．また，サンコ礁の重要性や，危機の状態， 危機の原因, 対策と課題などの詳細な情報の提供有無の 反応をみるため, 総サンプル数の $70 \%$ には参考情報ペー ジの提供を行い（図-4), 残りの $30 \%$ に情報提供を行わ なかった. ここで, 両者の比率は特に意味はなく, 参考 情報の提供有無による関心度や関心事項への影響を, ク ロス集計した後の比率で比較するのに用いる.

表-2 インターネット調查の設問項目

\begin{tabular}{|c|c|c|c|}
\hline 項目 & データ & $\begin{array}{l}\text { カテゴ } \\
\text { リ一数 }\end{array}$ & カテゴリー- \\
\hline 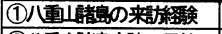 & SA & 4 & ない, 1 2回 3回, 4回以上 \\
\hline (2)八重啫岛来訪の目的 & MA & 11 & 周遊覞光 ダイビング・シ】ー似グ など \\
\hline $\begin{array}{l}\text { (3八重山産島に抱く魅力的 } \\
\text { なイメージ }\end{array}$ & MA & 14 & $\begin{array}{l}\text { きれいな青い海 豊かなサンゴ礁や魚の } \\
\text { 群れ，八重山の文化·歷归お十など }\end{array}$ \\
\hline (4)八重上䰇島への施行意欲 & SA & 6 & 预がある，ぜい旅䛃したいなど \\
\hline $\begin{array}{l}\text { 5)八重山賭島の旅行で行い } \\
t \text { たこと }\end{array}$ & MA & 25 & 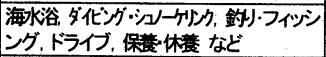 \\
\hline 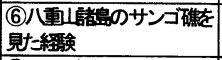 & MA & 5 & $\begin{array}{l}\text { 海の中で見た，水㵀館で見た，写真や映像 } \\
\text { で見たたど }\end{array}$ \\
\hline \begin{tabular}{|l|} 
7)サンゴ礁の危機への関 \\
心度
\end{tabular} & SA & 4 & $\begin{array}{l}\text { 非常二関しを持つ，ある程度関しを持つ, } \\
\text { あまり関しを持たない，ほとんど持たない }\end{array}$ \\
\hline \begin{tabular}{|l|} 
8)サンゴ礁の危機に対す \\
る関し事項
\end{tabular} & MA & 9 & 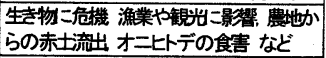 \\
\hline \begin{tabular}{|l|}
$\begin{array}{l}\text { 9)サンゴ礁の保全·再生の } \\
\text { ためめに必要よ対策 }\end{array}$ \\
\end{tabular} & MA & 12 & 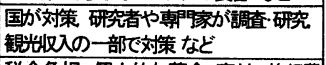 \\
\hline \begin{tabular}{|l|} 
10サンゴ礁の保全·再生の \\
たニめの資金提供手段
\end{tabular} & MA & 7 & $\begin{array}{l}\text { 税金負担，個人的な募金·寄付，旅行費 } \\
\text { 用等一部阹カハパ，里親やオ一ナ一など } \\
\end{array}$ \\
\hline 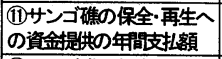 & SA & 11 & $\begin{array}{l}500 \text { 円末萬 } 500 \text { 円 1,000円 } 1,000 \text { 円〜 } \\
3,000 \text { 円, 3,000円 5,000円 など }\end{array}$ \\
\hline \begin{tabular}{|l|} 
(12サンゴ礁の保全·再生へ \\
の資金题其のメリット \\
\end{tabular} & MA & 11 & $\begin{array}{l}\text { 証明書の発行, HP等に掲載 地場産品 } \\
\text { の割引特典，特典プレゼント など } \\
\end{array}$ \\
\hline \begin{tabular}{|l|} 
131サンゴ礁の保全·再生に \\
関連する企画への参繶向 \\
\end{tabular} & SA & 7 & $\begin{array}{l}\text { サンゴ礁生態観察ソア一，移植·再生の } \\
\text { ダイビングツアー，調查·研究活動 など }\end{array}$ \\
\hline $\begin{array}{l}\text { (14)サンゴ礁の保全·再生に } \\
\text { 関連する企画の年間支抽額 } \\
\end{array}$ & SA & 11 & $\begin{array}{l}500 \text { 円満 } 500 \text { 円 } 1,000 \text { 円 } 1,000 \text { 円 } \\
3,000 \text { 円 3,000円 5,000円 など }\end{array}$ \\
\hline 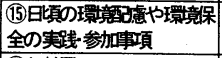 & MA & 21 & 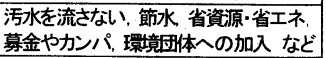 \\
\hline (16)年龄領 & SA & 6 & 20〜29歳, $30 \sim 39$ 歳 など 10 歳単位 \\
\hline 17世世带の年l双水準 & SA & 12 & 200 万円未満，200 万円台 など \\
\hline (18)性別 & SA & 2 & 男性 女性 \\
\hline (19)居住地 & SA 等 & - & （都道付県選択 市区田村記入 \\
\hline 20自由意見 & 記入 & - & (フリーアンサー) \\
\hline
\end{tabular}

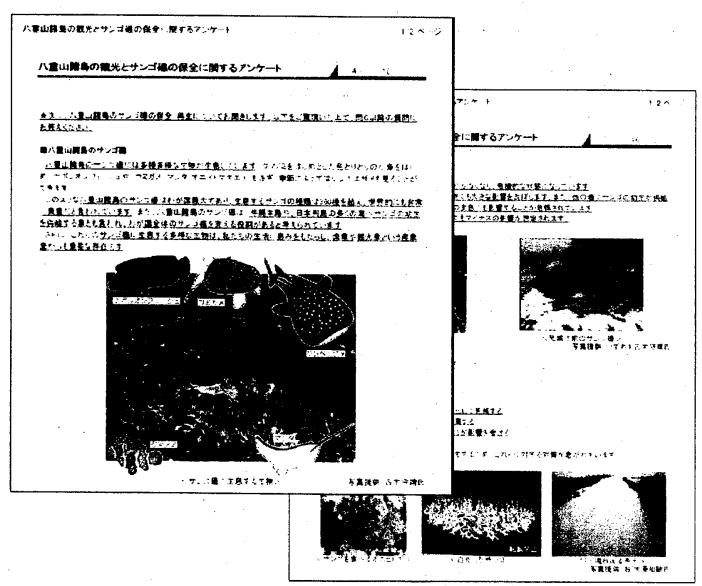

図-4 サンゴ礁危機の参考情報ベージ画面

\section{3. サンコ礁危機に対する関心}

ここでは, インターネット調査の結果から，八重山諸 島のサンゴ礁の危機に対する関心について分析する.

サンコ礁の危機に対する関心度は，図-5に示す通り，

「非常に関心を持つ」が約 $35 \%$ ，「ある程度関心を持つ」 が約 60\%と，多くが高い関心を示すことが確認された.こ の内，アンケートの設問の中でサンゴ礁危機の説明を行 った者と, それに加え, サンゴ礁の重要性や，危機の状 態, 危機の原因, 対策之課題などについて詳しい参考情 報ぺージを提供した者を比率で比較すると, サンゴ礁危 機に対する関心度においては比率に有意な差は認められ なかった（図-5).ただし，「全国のサンゴ礁への影響」, 「漁業や観光への影響」などの影響事項や、「農地からの 赤土流出」,「水質污濁」、「オニヒトデの食害」などのサ ンゴ礁减少の原因事項については有意な差が認められた (Z 検定による，図-6)。このことから，サンコ礁の危機 に関する詳細情報を提供することで，その影響や原因に 関する事項について関心を高め, 理解を促すことができ ると考えられる.

また，この参考情報ページの提供有無は，他の設問項 目とのクロス集計においては有意な差がほとんど認めら れなかった. 即ち, 参考情報の提供によって, サンゴ礁 危機の影響や原因に関する事項への理解は深まるものの, サンゴ礁危機の関心度や，後述する資金提供額などには 影響しない.「サンコ礁危機」という話題自体に観光客が 反応し，それが態度や行動につながるのではないかと推 察される.このようなことから, 以降の集計・分析は全 サンプルを対象としている.

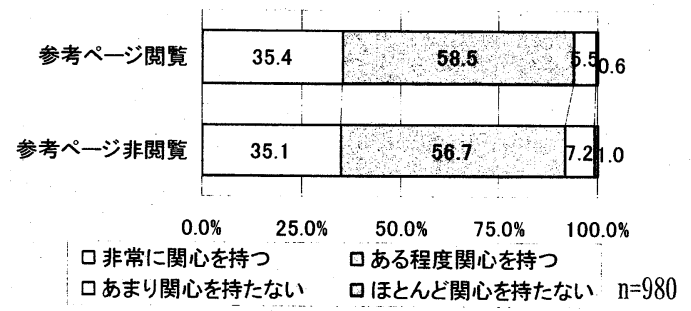

図-5 サンコ礁危機の関心度（参考ベーシ閲覧有無）

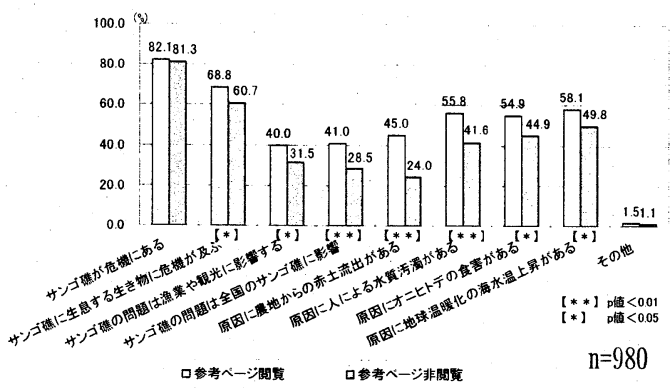

図-6 サンコ礁危機の関心事項（参考べージ閲覧有無） 
また，このサンゴ礁危機への関心度に影響を及ぼす要因 を明らかにするため, 想定できる事項之関心度の関係に おいてクロス集計を行った結果，「八重山諸島への来訪経 験」「旅行意欲」,「ダイビング・シュノーケリング経験,

「サンコ礁を見た経験（図一7)」「旧常的な環境配慮事項 の数 (図-8)」,「年齢層」などに相関がみられた.

このような相関があった項目からサンコ礁危機への関 心を規定する要因を導出するため, 数量化理論 2 類を用 い分析を行った（目的変数は 4 段階の関心度を[非常に関 心を持つと「それ以外」の 2 カテゴリーに統合)．計算 過程では, 多重共線性に留意し説明変数どうしで相関が 強い変数 (ララメール俰数>0.50)のうち, 目的変数と相 関が小さい方を削除して計算を行った. その結果, 予測 式の相関比は 0.15 と精度は高くはなかったものの，「サ
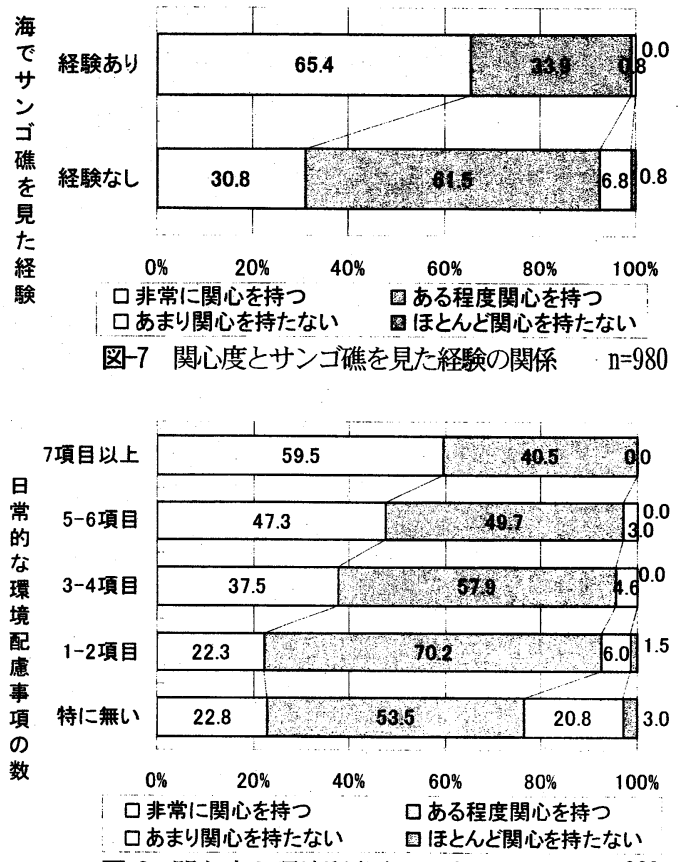

図-8 関心度と環境配慮事項の数の関係 $\mathrm{n}=980$

表-3 サンコ礁危機の関心度に関する数量化理論 2 類の結果

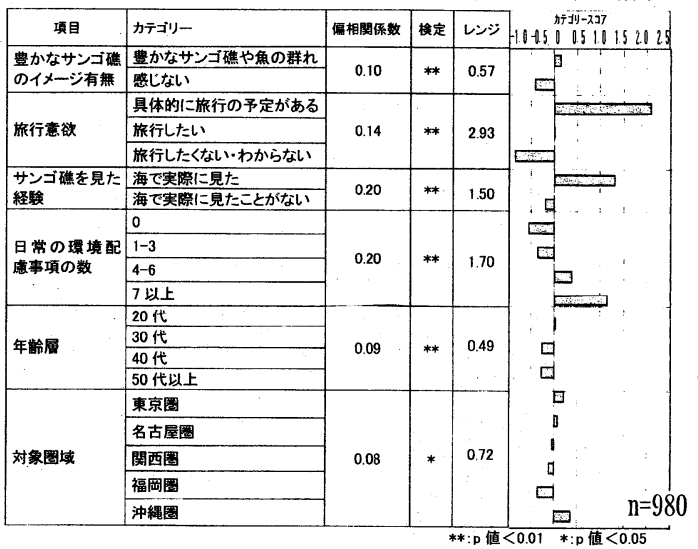

ンゴ礁を見た経験（偏相関俰数：0.20)」,「日常的な環境 配慮の経験度（偏相関係数 : 0.20)」,「旅行意欲（偏相関 係数:0.14)」などが主要な要因として導出された (表-3).

このようなことから, サンゴ礁危機への協力の呼びか けの対象として，環境配慮層や旅行意欲者をターゲット とすることが有効と考えられる. また，サンゴ礁危機へ の関心をさらに高めるには，実際にサンゴ礁を見てもら うことが重要であると考えられる.

\section{4. サンコ礁保全·再生に対する参加・協力の意向}

ここでは, サンコ礁の保全·再生の対策に対する考え方, 資金提供の方法やその額, 資金提供の際のインセンティ ブについて分析する. 保全·再生の対策に対する考え方に ついては, 図-9に示す通り,「研究者·専門家が調査·研究」, 「国が対策」に続き，「観光収益の一部を使う」、「企業が 社会貢献活動として支援」、沖縄県や地元の市町村が対 策」などに回答が多かった. また，「観光客や国民が対策 に参加」も少なくなく, 研究者・尃門家, 国, 自治体に 加えて, 観光客や企業の参加を求める意見が多く存在す ることが確認された。

サンゴ礁保全·再生に対する個人の資金提供の手段と しては，「旅行費用の一部をカンパ」「個人的な募金・寄 付」,「特産品や商品を通販などで購入（収益の一部を充 当)」に比較的多くの回答があった（図-10). また，回答 者が実際に支払うことができる年間の合計金額について，

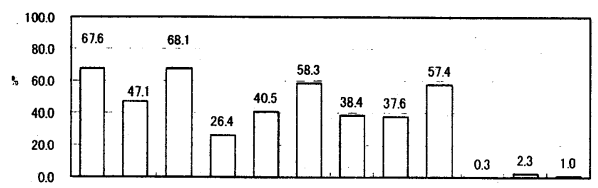

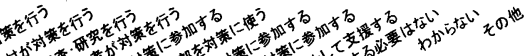
圂-9 サン碓保全.再生の対策の考え方 $\mathrm{n}=980$

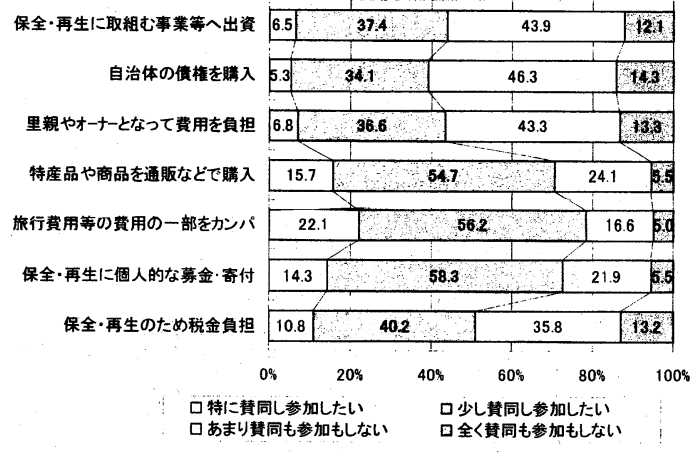

図-10 サンコ礁保全·再生への資金提供手段 n=980 


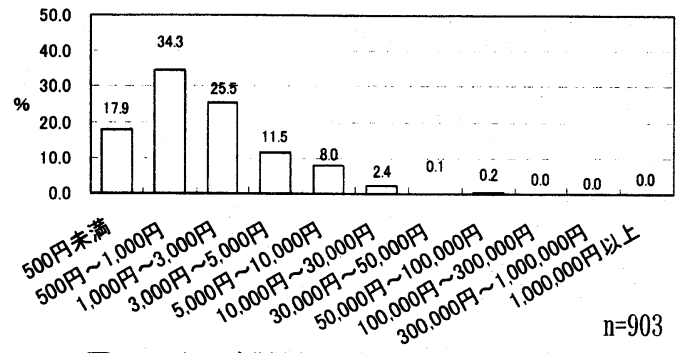

図-11 サンコ礁保全·再生への年間資金提供額

選択式で回答してもらったところ，500～1,000 円が最も 多く, 次いで, 1,000 3, 000 円, 500 円未満之, 3, 000 円以下の資金提供の意思を持つ者が多いことが分かった

（図-11）。この資金提供額は先に示した資金提供手段の 選好による差異は少なかった.

ここで, CWM 法で多く行われている二項選択方式ではな く選択回答方式を用いたのは，実際の資金提供時には一 口単位での資金提供を求める（一口千円など）ことがあ ることや，資金提供時に貨幣の硬貨や紙幣の単位が影響 する（千円札を一枚募金するなど）などの資金提供時の 行動を勘案したためである.

また，この資金提供額の回答分布に従い，仮に平成 17 年度の八重山諸島の航路入域者数 $\left(618,112\right.$ 人) $\left.{ }^{12}\right)$ の 人に 1 人が資金提供を行ったとして計算すると, 年間合 計約 3 億 2 千万円程度の資金が回収できることになる. 課題は，観光客に資金提供をどのように要請し，どのよ うに回収するかという資金回収の手段の開発である. 資 金回収の手段によって，回収額が大きく変動すると考え られる. 例えば，八重山諸島への入域者はほとんどが航 路利用のため, 航空会社とタイアップして資金提供を求 めることが有効と考えられる.

この資金提供額を規定する要因を明らかにするため, 数量化理論 1 類を用いて多重共線性に留意して分析を行 った（月的変数は各選択回答の平均額とし, 回答数が少 なかった 10,000 円以上は除外した $\mathrm{n}=889)$ ところ, 決 定係数が 0.16 と予測式の精度は低いものの, 「サンゴ礁 危機問題への関心度 (偏相関係数 : 0.13)」,「里視やオ一 ナ一となって費用負担（偏相関係数：0.10)」,「世帯年収 の多さ（偏相関倸数 : 0.10)」,「旅行費用等の一部をカン パ(偏相関係数 : 0.10)」などが導出された. このことか ら, 八重山諸島のサンコ礁の保全·再生に資金提供を求め ていくには，(1) サンコ礁危機への関心を高める， (2) 高 収入層をターゲットとする, (3) 観光客にサンゴの里親や オーナーとなってもらう, (4) 旅行費用の一部のカンパを 求めるなどが有効と考えられる. なお, 計算精度が高く なかった理由として, 分析に用いなかった要因（先述し た硬貨や紙幣の単位などの資金提供時の行動に関する要 因など）が影響している叮能性が考えられる。
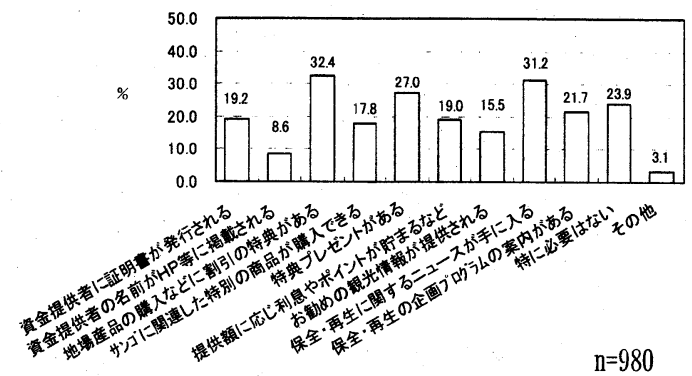

図-12 資金提供時のインセンティブ

$n=980$

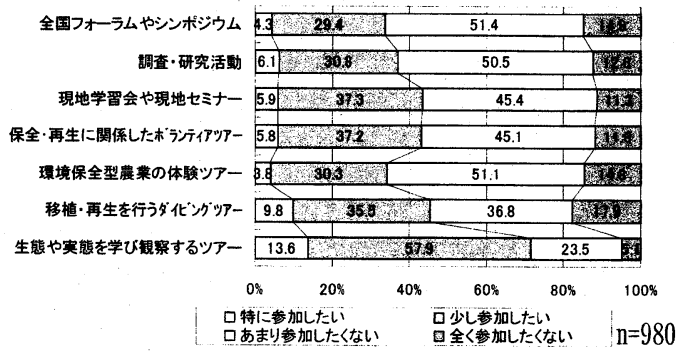

図-13 サンゴ礁保全・再生に関する企画への参加意向

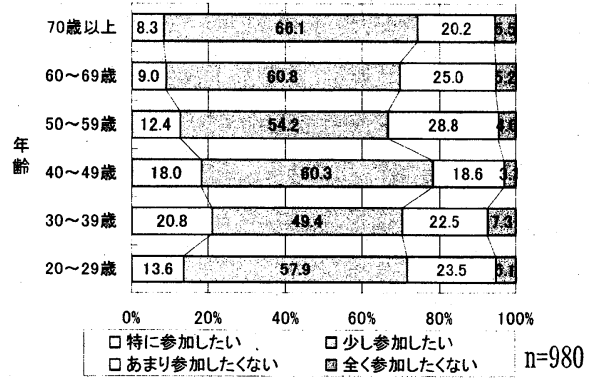

図-14 年齢層とサンゴ礁生態観察ツアーの参加意向の関係

資金提供時のメリットについては, 図-12に示す通り, 「地場産品の購入などの割引の特典」,「保全・再生に関 するニュース」,「特典プレゼント」,「保全·再生の企画プ ログラムの案内」などの回答率が高かった. 即ち, この ようなインセンティブを用意することで, 資金提供の行 動が促せると考えられる.

次に, サンコ礁の保全·再生を月的とした観光ツアーや イベントなどの企画に参加を促し，その参加資金を保全· 再生に充当するという手段も考えられ，そのような企画 への参加意向とその支配額を分析する. まず, サンゴ礁 の保全·再生に関連した企画の参加意向としては, 図-13 に示す通り,「生態や実態を学ひ観察するツアー」への回 答が最も多かった. この「生態や実態を学び観察するツ アー」はどの年齢層からも回答が集まった（図-14). 先 述の通り, サンゴ礁危機の関心喚起のためには, 実際に サンゴ礁を見てもらうことが重要であることから，この ような観光ツア一の企画・開発が有効と考えられる. また,

「移植·再生を行うダイビングツアー」については，ダイ ビング・シュノーケリング経験者や願望者，30４9歳の 
年齢層との関連性が認められ，航空会社などが開発して いるサンコ移植ツアーのニーズか確認された.

このような企画に個人が年間に支払える参加費用（八 重山諸島までの旅費を除く）については，1,000〜3,000 円が最も多く, 次いで, 500 1, 000 円, 3, 000 5, 000 円, 5, 000 10,000 円と, 10,000 円以下が多く, 先の直接的 な資金提供を求めた場合に比べてその額は増大する傾向 にある (図-15).このことから, サンゴ礁の保全·再生に 関連した観光ツアーを企画し，それに組合せて資金提供 を求めていくことが効果的と考えられる. また，この支 払額の回答分布に従い, 仮に平成 17 年度の八重山諸島の 航路入域者数 $\left(618,112\right.$ 人) $\left.{ }^{12}\right)$ の 5 人に 1 人が企画に参加 したとすると，年間合計約 6 億 4 千万円程度の資金が回 収できることになる。

支払額を規定する要因を明らかにするため, 数量化理 論 1 類を用いて分析を行った（目的変数は各選択回答の 平均額とし, 回答数が少なかった 30,000 円以上は除外し た $\mathrm{n}=774 ）$ ところ, 決定係数が 0.11 と予測式の精度は 低いものの,「世帯年収の多さ (偏相関係数: 0.15)」,「圈 域の違い（偏相関係数 : 0.12）」,「ダイビング経験（偏相 関係数 : 0.07)」などが主要な要因として導出された.こ のことから, サンゴ礁の保全·再生の企画においては，高 収入層, 名古屋圈・関西圈・東京圈の居住者, ダイビン グ経験者をターゲットに企画開発をすることなどが有効 と考えられる.

以上を整理すると,サンコ礁の保全·再生に向けて観光 客の関心を高め, 資金提供や企画ツアーへの参加·協力を 求めていくには，図-16に示すように，(1)八重山諸島の サンゴ礁の生態や実態を観察するツアーの企画・開発を
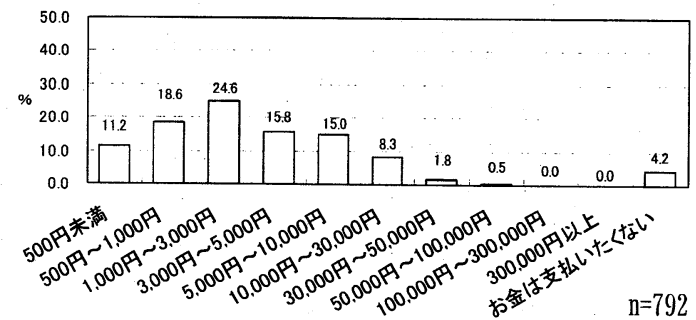

図-15 サンコ礁保全・再生の関連企画への参加の年間支払額
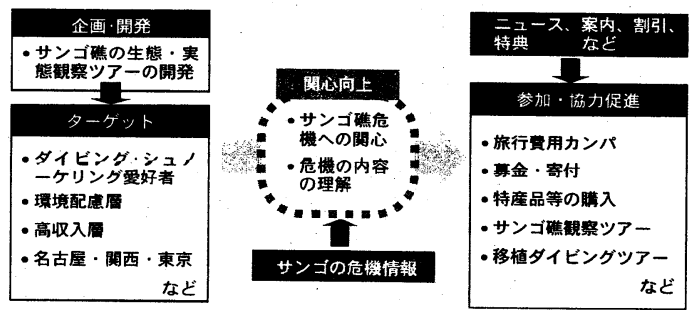

図-16 サンコ礁の保全·再生への参加・協力促准の方策
進め, (2) 適当なターゲット (ダイビング・シュノーケリ ング愛好者, 環境配慮層, 高収入層, 名古屋・関西・東 京圈住民など）に働きかけ，(3) 資金提供を促すインセン ティブ (割引特典, ニュース, 企画プログラムの案内な ご）を与え，(4) 旅行費用のカンパや，募金・寄付，関連 特産品等の購入などで資金提供を求めることが効果的で ある. また，(5) サンゴ礁の危機に関する情報提供を行う ことは観光客の理解を深めることに有効である.

\section{5. 観光とサンコ礁保全·再生のリンクの可能性}

ここでは，以上の結果を参考に，八重山諸島の観光と サンゴ礁の保全·再生とのリンクの可能性について分 析・考察する. インターネット調査から，八重山諸島に 旅行したいとする者は多く（「具体的に予定がある

(1. 7\%)」，「予定はないがぜひ旅行したい (42.1\%)」，「機 会があれば旅行したい $(50.9 \%) 」)$, 旅行での体験二ーズ は様々に分散することを確認している. そこで，ここで は, 数量化理論 3 類を用いて体験二一ズの傾向を分析し た（この際，回答が $5 \%$ 未満のカテゴリーは除外した $\mathrm{n}=924)$ ．その結果，図-17 に示す通り，「海を直接体験夕 イプ」,「海を間接体験夕イプ」,「八重山堪能夕イプ」,「健 康づくりタイプ」,「ショッピング・見学タイプ」の 5 つの タイプに分類できた. そこで, 今までの分析結果をもと に, この 5 つのイフフ別に観光とサンコ礁の保全·再生の リンクについて整理すると図-18 の通りである.この中で, 最もターゲットとすべきは，「海を直接体験夕イプ」であ り, サンゴ礁生態・実態観察ツアーやサンコ礁再生ツア 一などの企画を組み込み，旅行費用のカンパ，募金・寄 付, 特産品の購入を求めていくことが有効である. また,

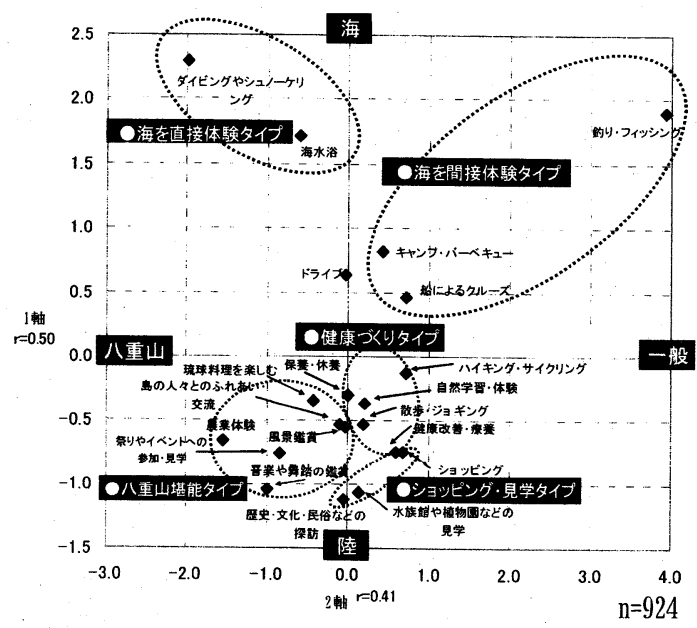

図-17 八重山諸島での体験二ーズの傾向（数量化 3 類） 


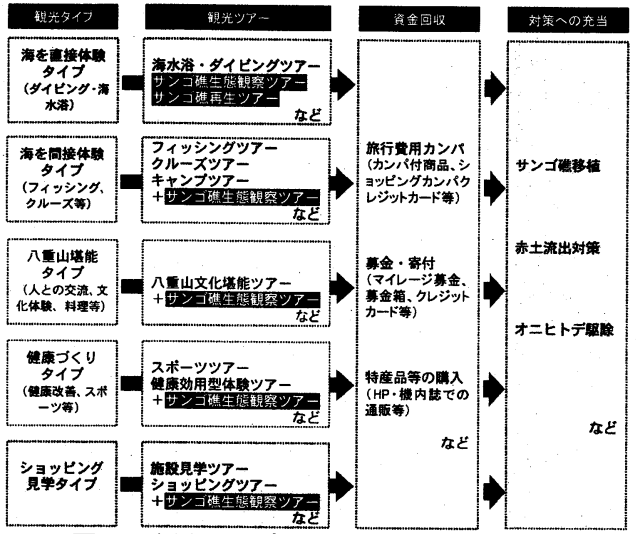

図-18 観光夕イプ別の参加・協力の促進方法

その他のタイプについても, サンコ礁の生態·観察に触れ る機会を観光ツアーの中に組み込み, サンゴ礁危機の情 報提供を与えることで理解を深めつつ, インセンティブ を働かせて, 旅行費用のカンパ, 募金・寄付, 特産品の 購入を求めていくことが望ましい. また, 航空会社との 提携など，観光客の資金提供の意思に対応できる適当な 資金回収手段の開発が肝要である.

\section{6. おわりに}

本研究では, 沖縄地方の赤土流出問題の解決に向けた基 金の可能性を追求するため, 八重山諸島の観光マーケッ 卜の圈域住民を対象にインターネット調査を行いその結 果を分析・考察した. その結果, (1) 八重山諸島のサンゴ 礁危機に対する関心は高く, 情報提供によってその理解 が深まること, (2) サンコ礁危機への関心を高めるにはサ ンゴ礁に触れる機会を設けること，(3) サンコ礁の保全・ 再生への観光客の年間資金提供額は 3,000 円以下で，資 金提供を促すには関心を高め, ターゲットを設定し適当 なインセンティブと回収方法を工夫すること，(4) サンゴ 礁の保全·再生に関連した企画には 10,000 円以下の支払
が望め, サンゴ礁の生態·実態を観察するツアーの企画開 発が有効であること，(5) 観光ツアーと組み合わせてサン ゴ礁の保全·再生に参加・協力を求めることが有効である ことなどが確認された. 今後は, 航空会社を含む企業の 参加・協力の可能性について研究を深め, 実効的な基金 制度などの流域経営システムを確立していきたい. 最後 になったが, 本研究は国土交通省平成 18 年度建設技術研 究開発費補助事業の研究助成を受けていることを記す.

謝辞 : 本研究の実行にあたり様々な意見交換を頂いた全 ての関係者に謝意を表すものである.

\section{参考文献}

1) 大澤和敏:沖縄における赤土等流出問題の総合的研究 (社) 沖縄建設弘済会, 2006. 3.

2）[特許] 発明者: 岡本峰雄・古島靖夫·野島哲，サンゴ礁の人 工増殖具及乙゙増殖方法，特許第 3530832 号 2004 年 3 月 5 日，特許権者:海洋科学技術センタ一。

3）松下潤他：沖縄における流域経営と赤土流出抑制システム の促進方策に関する研究 国土交通省平成 17 年度建設技術 研究開発費補助事業研究報告, 2006 .

4) 宮本善和·成瀬研治·松下潤·惠小百合:沖縄地方の赤土流出 防止に向けた流域経営システムに関する研究一基金制度の 視点からー, 第 13 回地球環境シンポジウム講演論文集, pp. $65-70,2005$.

5）宮本善和·成瀬研治·松下潤·惠小百合:沖縄地方の赤土流出 抑制に向けた流域経営システムの可能性に関する研究 第 14 回地球環境シンボジウム講演論文集, pp. 151-156, 2006.

6) 栗山浩 : 環境の価値と評価手法-CW による経済評価, 北 海道大学図書刊行会, 1998 .

7）大野栄治 : コンジョイント分析による伊勢湾の環境価値の 経済評価, 日本沿岸学会論文集, No. 13, pp. 65-74, 2001.

8）鈴木武・滝川清 : コンジョイント分析による有明海の環境 改善に対する支払意思の推定，第 34 回環境システム研究論 文発表会講演集, pp. 85-90, 2006.

9）関いずみ・富田宏:都市漁村交流による環境社会システムの 再編と発展の可能性について, 第 13 回地球環境シンポジ ウ厶講演論文集，pp. 183-188，2005.

10）米山秀隆:経済社会の変革を促す市民富士通総研研究レボ 一ト, No. 226, 富士通総研経済研究所, 2005.

11）城戸幸子・市川新 : 地域通貨を通じた環境保全型社会シス テムの構築, 第 31 回環境システム研究論文発表会講演 集 pp. 457-462, 2003.

12）沖縄県八重山支庁総務・観光振興課 : H17 年入域観光統計

13）那覇市: 那覇市の観光統計一観光客の声一（平成 16 年版)

\title{
THE SOCIAL MARKET OF WATERSHED MANAGEMENT FOR CONTROL OF THE SOIL DISCHARGE AND PRESERVATION OF THE CORAL REEF IN OKINAWA DISTRICT
}

\author{
Yoshikazu MIYAMOTO, Kenji NARUSE and Jyun MATSUSHITA
}

\begin{abstract}
The soil erosion at farmland becomes serious impact on the ecosystem in the coral reef in Okinawa district. In order to solve these problems, it is necessary to build a support system for the integration of the measures in a river basin. This paper examines the social marketing research using the internet of watershed management for the support system as follows, 1) the interest for the crisis of the coral reef at Yaeyama Islands, 2) the intention to offer a fund for preservation of the coral reef, 3) the linkage of the tourism and the preservation of coral reef.
\end{abstract}

